\title{
Rural Infrastructure Development Fund (RIDF): Contribution for Rural Development in North-East Region
}

\author{
Miss. Rimjhim Bordoloi \\ Department: - Economics \\ Ph.D Research Scholar \\ Rajiv Gandhi University \\ Itanagar, Arunachal Pradesh, India
}

\author{
Mr. Bhoirab Jyoti Konch \\ Department: - Economics \\ Ph.D Research Scholar \\ Rajiv Gandhi University \\ Itanagar, Arunachal Pradesh, India
}

\begin{abstract}
Poverty is well recognized as major problems of less developed country like India. Though both central and state government takes various five year plans and poverty alleviation schemes, yet, the problem of mass poverty, growing unemployment and large scale migration to urban area persist in rural areas. It is not possible for us to reduce the burden of poverty as well as the level of unemployment. About $40 \%$ of people in rural area still lives below poverty level. In this paper attempted to make the role of Rural Infrastructure Development Fund for rural development in north east region with the help of secondary information. It is found that under RIDF a lot of very important scheme and funds are provided for the upliftment of the rural areas. But due to the lack of strong financial position, weak functioning of NGOs, PRIs, SHGs and etc. are badly affect on the proper utilization of the benefits of the RIDF in North-East region. It is clear from the study that without developing infrastructure facility of rural areas, it is impossible for the country to achieve its goal of development of all sectors of the country.
\end{abstract}

Keywords: Rural Development; North-East Region; Poverty; Infrastructure.

\section{INTRODUCTION}

Poverty is well recognized as major problems of less developed country like India. Though both central and state government takes various five year plans and poverty alleviation schemes, yet, the problem of mass poverty, growing unemployment and large scale migration to urban area persist in rural areas. It is not possible for us to reduce the burden of poverty as well as the level of unemployment. About $40 \%$ of people in rural area still lives below poverty level. This is mainly because of landless agricultural labourers and small and marginal farmers are not able to earn sufficient income from agriculture. The development of rural areas is only possible through the development of infrastructure facilities of the rural areas. The infrastructure can be considered as the "wheels of economic activity" because inadequate in the availability or failure of existing infrastructure facilities quickly and radically reduces the quality of life. Therefore, the demand for infrastructure services from business, households and other users increased very rapidly during the past two decades.

In a broad sense, infrastructure means the stock of fixed capital in an economy, viz. factories, roads, school, etc. considered as determinant of economic growth. The development of agriculture and industrial sectors depends directly on good infrastructure facilities. But the scenario of infrastructure development of north east region of India is not encouraging. The collective index of infrastructure of the region is also very low in comparison with other states of the country. As per Center for Monitoring Indian Economy, Bombay, the collective development indices for infrastructure are 44, 93, 81,65,63,71 and 63 in the states of Arunachal Pradesh, Assam, Manipur, Meghalaya, Mizoram, Nagaland and Tripura respectively where as for Punjab and Haryana the score of collective development index for infrastructure is 214 and 149 respectively. The electricity facility as well as road facilities is poor in the rural areas of north eastern region. The degree of electrification of villages in the region is almost as par with India

(NER 82.8; India 84.4) but per capita consumption of electricity is much less (100 KWH/year against 240 $\mathrm{KWH} /$ year in India). Meghalaya is known to be a powersurplus State, this is mainly due to the lowest degree of rural electrification and poor per capita of power. Again it is found that, the ratio of surfaced road to total road length in NER is 0.27 against 0.51 in India and road length per $100 \mathrm{sq} \mathrm{km}$ of area is $46 \mathrm{kms}$ against 64 in the nation. The railway facilities are also not up to the expected level. Still a lot of rural areas of north east region are far away from the facility of railway. In 1985 about 48 percent of the villages in the NE region were identified as problematic villages with respect to availability of water. This figure was only 28 percent for the nation. Over the years, this problem has been addressed to, but much is yet to be done. There is an urgent need to improve the conditions of these problem villages. The north east region lacked basic infrastructural facilities due to geographical isolation and difficult terrain surrounded by hills, rivers and dense forest and it has still remained very poor in her economic infrastructure in spite of getting priority in the Five Year Plans. It is universally recognized that an adequate supply of transportation, communication and power infrastructure facilities can do much to boost productivity and subsequent economic growth. The World Bank (1994) observed that a reasonable minimum package of transport, telecommunication and power at the village level was the major ingredient in the success of rural enterprises in China. These enterprises now produce more than a third of national output and employment more than 18 million people. 
In order to develop the infrastructure of the region, various developmental agencies, central and state government and institutions had initiated various schemes such as IRDP, PMRY, and TRYSEM etc. But these programs were not able to achieve its goal. Still central government is introducing many new schemes through state governments for the development of infrastructure in rural areas. Among of them an important scheme undertaken by central government through National Bank for Agricultural and Rural Development (NABARD) is Rural Infrastructure Development Fund (RIDF) established in 1995-96.

\section{RURAL INFRASTRUCTURE DEVELOPMENT FUND (RIDF)}

The RIDF was instituted in NABARD with an announcement in the Union Budget 1995- 96 with a corpus fund of Rs. 2000 cores within National Bank which would be funded by the commercial Bank from out of their shortfalls under lending for agriculture. The sole objective of the RIDF is to give low cost fund support to state government and State Owned Corporation for quick completion of ongoing projects relating to medium and minor irrigation, soil conservation, watershed management and other forms of rural infrastructure. The term of loan under RIDF is 7 years (phasing of project: 3 years). The current rate of interest is $6.5 \%$. The hon'ble Union Finance Minister, Dr. Manmohan Singh in his budget speech on 15 March 1995 stated that, "Inadequacy of public investment in agriculture is today a matter of general concern. This is an area, which is the responsibility of states. But many states have neglected investment in infrastructure project, which have been started but are lying incomplete for want of resources. They represent a major loss of potential income and employment to rural population." Every year the allocation to RIDF is being met through announcement in the Union Budget, after which RBI prepare the list of bank - wise allocation based on the priority sector shortfall by each bank. Under RIDF I, the fund was allocated from the shortfall in sub target $(18 \%)$ for agriculture under priority sector lending with a ceiling of $1.5 \%$ of net bank credit. From RIDF II to XIV, the funds were allocated from shortfall in priority sector lending (40\%) and agriculture (18\%). From RIDF XV onwards, the allocation to RIDF is being met out of shortfall from priority sector/agriculture/ weaker section (10\%). The RIDF operation are governed by Section 27A of NABARD Act, 1981 which inter-alia stipulates: "National Bank may make loans and advances to any state government...as may be approved by the Board, for the purpose of development of infrastructure facilities for promotion of agriculture and rural development". In 2014, the Union Budget has proposed to raise the corpus of RIDF by an additional Rs. 5,000 crore. In addition, an amount of Rs. 100 crores has been set aside for the Agro- tech infrastructural funds.

Under RIDF-XIV, loans will be available as per the following norms under RIDF-XIV---

Table I.

\begin{tabular}{|l|l|l|l|}
\hline Sl. No & Sector/ Activity & $\begin{array}{l}\text { RIDF loan admissible as \% age of eligible project cost } \\
\text { for projects from hill states of Himachal Pradesh, } \\
\text { Jammu and Kashmir, Uttarakhand and North east states } \\
\text { including Sikkim }\end{array}$ & $\begin{array}{l}\text { RIDF loan admissible as \% eligible } \\
\text { project cost for projects from states } \\
\text { other than mention in column (3) }\end{array}$ \\
\hline 1 & 2 & 3 & 4 \\
\hline 1 & $\begin{array}{l}\text { Activities related to agriculture such as irrigation, } \\
\text { soil, conservation, flood protection etc. }\end{array}$ & $95 \%$ & $95 \%$ \\
\hline 2 & Social sectors projects & $90 \%$ & $85 \%$ \\
\hline 3 & & $90 \%$ & $80 \%$ \\
\hline
\end{tabular}

RIDF, set up in 1995-96 with the National Banks, received an increased allocation of Rs. 5,000 crores during 2001-02, of which an amount of Rs. 750 crores were earmarked for rural electrification projects and Rs. 500 crores for rural infrastructure projects to be implemented through SHGs/NGO/PRIs etc. The NABARD has plans to sanction a loan of Rs. 800 crore in the financial year, 2013-14 under RIDF. The disbursement made under RIDF was Rs. 750 crore in the last fiscal year. In addition to credit support extended to state government and banks, NABARD also disbursed Rs. 18.37 crore as grant assistance for various promotional programmes in the state like farmers club, technology transfer, watershed development etc. Cumulatively, the total number of completed projects reached 1679 under various sectors till 31 March 2013. Thus, a number of 830 completed road projects added 5297 kilometers of roads to the state road network and 455 rural bridges facilitating rural connectivity.

It is seen that NABARD has raised allocation by $18 \%$ for the seven sisters as the under developed north east is now main focus of the present government. Assam and Tripura are better off than other states in the region. NABARD sets the sanction target for Arunachal Pradesh at Rs. 160 crore, compared with Rs. 50 crore in 2011, while it doubled the target for Meghalaya and Nagaland at Rs. 120 crore and Rs. 50 crore respectively. NABARD under RIDF disbursed Rs. 14,970 crore during 2011-12, which was Rs. 2,900 crore or $24 \%$ more than the disbursement made to state government during 2010-11. The amount of sanction given by NABARD under the RIDF also increased to Rs. 21,460 crore, which was over Rs. 3,000 crore more than the sanction during the previous year. Again it is found that the level of disbursement under RIDF increased to $16,292.26$ crore during 2012-13. The amount of sanction also increased to Rs. 20,588.34 crore in 2012-13. In 201314 , there is a tremendous growth of the disbursement level under RIDF i.e. it increased to Rs. 17,353 crore which is a growth of $6.51 \%$ over the previous year. Thus, it is observed that the importance on infrastructural development has increased gradually. This is shown with the table given below 
Table II.

Sanction and Disbursement in north east state wise as on 2007 (Rs Crore)
\begin{tabular}{|l|l|l|}
\hline STATE & SANCTIONS & DISBURSEMENT \\
\hline Arunachal Pradesh & 507.53 & 233.65 \\
\hline Assam & 1344.35 & 575.76 \\
\hline Manipur & 45.09 & 10.51 \\
\hline Meghalaya & 197.36 & 130.87 \\
\hline Mizoram & 117.64 & 102.80 \\
\hline Tripura & 186.31 & 115.50 \\
\hline Sikkim & 315.64 & 115.94 \\
\hline Nagaland & 78.74 & 61.30 \\
\hline Total & 2792.66 & 1346.33 \\
\hline
\end{tabular}

Rural Infrastructure and Employment Generation under RIDF according to the Annual Report NABARD 2001-02 can be shown as below-

Table III.

\begin{tabular}{|r|l|l|}
\hline \multicolumn{2}{|c|}{ Rural Infrastructure and employment generation under RIDF (irrigation, rural roads and bridges) } \\
\hline S1. No & Particulars & Total \\
\hline 1. & Irrigation creation of potential (lakh ha) & 67.19 \\
2. & Contribution of GDP (Rs. Crore) & 77.39 \\
& Employment Generation & 36.87 \\
& (a)Recurring (no. of jobs in lakh) & 9664.74 \\
& (b) Non recurring (lakh man days) & $1,19,317$ \\
& Roads and Bridges & $2,22,071$ \\
& (a)roads length (km) & 11178.11 \\
\hline
\end{tabular}

The assistance provided under RIDF for rural infrastructure projects has facilitated the expansion of the production base in rural areas and creation of additional employment opportunities. The performance till the end of 31st March 2002 is shown in the above table. The table of reference is broadly classified into irrigation and road and bridges. Under the irrigation sector so far 67.19 lakh hectares of land has created potential for cultivation with irrigation facilities and contributed Rs. 77.39 crore to GDP of the nation. It also generated 36.87 lakhs recurring and 9664.74 lakhs man days of non recurring jobs. Likewise, under this scheme so far roads of $1,19,317 \mathrm{kms}$ long and bridges of 2,22071 kms long have been constructed.

But, if we look at the sanction and disbursement of fund from RIDF at national level, then Uttar Pradesh accounts the higher receiver of RIDF amounted to Rs. 1604.56 crores against the sanction of Rs. 2608.80 crores which is more than the total fund sanctioned to the entire north eastern region. Next to Uttar Pradesh, Andhra Pradesh and Maharashtra share the maximum benefits of Rs. 1591.89 crores and 1397.04 crores respectively from RIDF. Among the states and union territories of the country, Manipur stood the least receiver of RIDF by receiving Rs.0.96 crores only. There are many constraints which are come on the way of proper implementation of the RIDF on the North East region of India. Among of them a few important are discussed below-

1. Delay in land acquisition for construction of canal, drainage, road and bridge and other infrastructure.

2. Delay in clearance from the concerned Environment Control Board.
3. Inadequate efforts towards capacity building of infrastructural agencies and towards human resources development.

4. Delay in procedural formalities within the state government.

5. Non-functioning of NGOs, PRIs, and SHGs in the states of the region at the expected rate.

6. Weak financial position of all the state governments in the region.

\section{CONCLUSION:-}

From the above discussion, it is seen that under RIDF a lot of very important scheme and funds are provided for the upliftment of the rural areas. But due to the lack of strong financial position, weak functioning of NGOs, PRIs, SHGs and etc. are badly affect on the proper utilization of the benefits of the RIDF in North-East region. It is clear from the study that without developing infrastructure facility of rural areas, it is impossible for the country to achieve its goal of development of all sectors of the country. Therefore, country should work together for developing the rural infrastructure. If the concerned state governments, state owned corporations, shelf help groups, and panchayati raj institutions of the region jointly work towards the development of rural economy by developing rural infrastructure through RIDF, it will be a boon for the rural development of the region. For achieving this goal, central government should provide separate funds for the development of North -East region of India and also central Government should provide ample scope for the development of infrastructure in rural areas of NE region through PM office. Thus, we may conclude by saying that, 
if we want higher growth rates for our fast economic development then, it is very important to make immediate huge investment on infrastructure of both physical and social. As we in India kept $8 \%$ growth per annum in Tenth plan, policy makers and planners should take correctly the stock of infrastructure existing and allot more funds for it, so that high growth in infrastructure can boost to high economic growth, as it is universally accepted.

\section{REFERENCES:-}

[1] Annual Report of NABARD

[2] Statistical statements, Annual Report,2001-02,NBARAD

[3] M.C. Behera. 'Globalization and Development Dilemma', 2004

[4] N.A. Khan. 'Infrastructure for Economic Development' 2004

[5] S.K. Mishra. 'Rural development in the North-Eastern Region of India: Constraints and prospects' June 21. 1999, MPRA 